\title{
Genetic diversity of the pampas deer (Ozotoceros bezoarticus) population in the Brazilian Pantanal assessed by combining fresh fecal DNA analysis and a set of heterologous microsatellite loci
}

\author{
Aline Meira Bonfim Mantellatto ${ }^{1}$, Renato Caparroz $^{2}$, Maurício Durante Christofoletti ${ }^{1}$, Ubiratan Piovezan ${ }^{3}$ \\ and José Maurício Barbanti Duarte ${ }^{1}$ \\ ${ }^{I}$ Núcleo de Pesquisa e Conservação de Cervídeos, Departamento de Zootecnia, Universidade Estadual \\ Paulista "Júlio de Mesquita Filho" (UNESP), Jaboticabal, SP, Brazil. \\ ${ }^{2}$ Departamento de Genética e Morfologia, Instituto de Ciências Biológicas, Universidade de Brasília, \\ Brasilia, DF, Brazil. \\ ${ }^{3}$ Centro de Pesquisas Agropecuárias do Pantanal (CPAP), Embrapa, Corumbá, MS, Brazil.
}

\begin{abstract}
The pampas deer (Ozotoceros bezoarticus) is close to being classified as 'globally threatened', with the largest population occurring in the Brazilian Pantanal. Since capture is stressful to these animals, non-invasive sampling methods such as the use of feces can provide reliable sources of DNA. The aim of this study was to use fecal samples to evaluate the genetic variability of the Brazilian Pantanal population of pampas deer. Six heterologous microsatellite markers were used to screen 142 stool specimens. Seventy-four deer were identified, of which 50 adults were used to determine the genetic characteristics of the population. The Pantanal population showed high genetic diversity (mean number of alleles per locus $=11.5$, expected heterozygosity $=0.75$ ). This is the first investigation to characterize a South American deer species using fecal DNA and demonstrates the usefulness and efficiency of this approach, as well as the feasibility of obtaining information that could not have been easily obtained by traditional DNA sampling. Our findings suggest that management strategies for this species may be much more effective if applied now when the population still shows high genetic variability.
\end{abstract}

Keywords: Conservation, fecal DNA, microsatellites, non-invasive methods, pampas deer.

Received: December 14, 2016; Accepted: February 20, 2017.

\section{Introduction}

Population genetic studies of wild populations of species of the family Cervidae have become feasible with the advent of fecal DNA analysis (Lounsberry et al., 2015; Yamashiro et al., 2015), particularly since these species have elusive habits and are usually listed as locally, nationally and/or globally endangered species. The capture of wild animals is potentially very stressful and can cause injuries (Greenwood, 1996; Duarte et al., 2010) with capture-related myopathy being frequently reported for species of this family (Catão-Dias and Camargo, 2010; Duarte, 2008). The fecal DNA technique allows researchers to economize financial resources and time, since conventional capture expeditions are extremely expensive and provide insufficient samples for population studies (Duarte, 2006).

Send correspondence to Aline Meira Bonfim Mantellatto. Núcleo de Pesquisa e Conservação de Cervídeos, Departamento de Zootecnia, Universidade Estadual Paulista "Júlio de Mesquita Filho" (UNESP), Jaboticabal, SP, Brazil. E-mail: alinemeira22@ hotmail.com
The pampas deer (Ozotocerus bezoarticus) is a medium sized (20-40 kg) Neotropical cervid with marked variation in body size among individuals and populations (González et al., 2010). The original distribution of this species included the Pampas region and practically all of the Brazilian Cerrado, from $5^{\circ}$ to $41^{\circ}$ south latitude, from the foothills of the Andean system to the Atlantic coast (Duarte, 2006; González et al., 2010). Although the pampas deer has historically had a wide geographical distribution, its habitat has been intensely reduced and fragmented by agriculture and urbanization, making this species the most endangered neotropical cervid (González, 1998).

To date, five subspecies of $O$. bezoarticus have been recognized based on morphological, genetic and geographical differences (Cabrera, 1943; González et al., 2002). The total population of $O$. bezoarticus leucogaster is estimated at 60,000 individuals (Mourão et al., 2000) and occurs in an area of 151,000 km2 (58,300 mi2) covering southwestern Brazil, Bolivia, Paraguay and northern Argentina. This subspecies is classified as vulnerable to extinction because of its likely future decline (estimated at $30 \%$ in the next 15 
years), attributable primarily to the introduction of pathogens via domestic ungulates (Duarte et al., 2001; Araújo Júnior et al., 2010) and to the tendency of substituting natural pastures (Duarte et al., 2012). According to the IUCN Red List, $O$. bezoarticus is considered near threatened; however, the populations in Argentina, Bolivia, Paraguay and Uruguay are considered endangered (González et al., 2016). Given the reduction and modification of their habitats, populations of pampas deer are becoming smaller and more isolated, with both of these phenomena increasing the species risk of experiencing reduction of genetic variability (González et al., 1998). Genetic variability can be rapidly lost in a population that remains small for many generations, raising the possibility of extinction of these populations (Frankhan et al., 2004).

To date, few studies have examined the genetic diversity of $O$. bezoarticus populations. González et al. (1998) examined sequences of the mitochondrial DNA control region in 54 individuals from six locations within the current distribution of pampas deer and verified that the surviving populations are small, isolated and genetically differentiated, except for two populations in Argentina. Furthermore, these same authors pointed out that the genetic variability of the control region observed in this species was one of the highest among mammals, suggesting that historically the population size of this species was much larger (estimated in millions of individuals) than it is today (estimated at $<$ 60,000, Mourão et al., 2000). In contrast, Rodrigues et al. (2007) studied the same two Brazilian populations studied by González et al. (1998) and found no genetic difference between them as assessed using nuclear molecular markers. These authors attributed the divergent results to genetic differences between the markers (mitochondrial DNA vs RAPD) used and male-biased dispersal. They also concluded that more studies using other nuclear molecular markers (such as microsatellites) are needed before genetic data can be used to guide conservation measures for this species. Cossé et al. (2007) and Cossé (2010, PhD thesis, Universidade de la Republica, Uruguay) described the only work that has used microsatellite molecular markers to genetically characterize the six populations of pampas deer in Uruguay, Argentina and Brazil, and the results corroborated the high genetic diversity of the species. Although Cossé (2010, PhD thesis, Universidade de la Republica, Uruguay) genetically characterized samples from 100 pampas deer, only seven of these were from individuals belonging to the Brazilian Pantanal population, which currently has the highest concentration of this species both in absolute numbers (Mourão et al., 2000) and in population density (Tomas et al., 2001).

In this study, we investigated the genetic variability of a population of $O$. bezoarticus leucogaster from the Brazilian Pantanal region by combining a non-invasive technique based on fresh fecal DNA analysis and the use of nuclear microsatellite markers. To our knowledge, this is the first study to associate these methodologies in an investigation of native ungulates in Brazil. Our main objectives were to evaluate the effectiveness of using fresh fecal samples and analyze a larger number of individuals in order to confirm that the studied population had high genetic diversity, as previously described.

\section{Materials and Methods}

\section{Sample collection and DNA extraction}

The stool sample collection area included the Nhumirim (experimental field of Embrapa Pantanal) and Alegria farms, located in the central region of the Brazilian Pantanal, known as Nhecolândia (1859'15" S; 56 37'03" N) (Figure 1). Deer were observed until they defecated in order to collect fresh fecal samples. All of the individuals sampled were classified in one of the following categories according to sex and age: adult male, young male, adult female, young female and undetermined. One hundred and forty-two fecal samples were collected. These samples were identified and stored in plastic bags and refrigerated (4 ${ }^{\circ} \mathrm{C}$ ) in a cooler with ice packs until they arrived at base camp, where they were frozen $\left(-20^{\circ} \mathrm{C}\right)$ and stored until processing in the laboratory. Total genomic DNA was extracted from the stool samples using QIAamp ${ }^{\circledR}$ DNA Stool mini kits (Qiagen), according to the manufacturer's recommendations.

\section{Heterologous primers}

The transferability of 11 heterologous primer pairs (Table 1) was evaluated in 13 blood samples from adult female $O$. b. leucogaster captured in the study area. The markers were selected because they showed cross-amplification with other Neotropical deer species, while seven of them (RT01, RT06, RT07, RT09, RT13, RT30 and CA71) had proven transferability to five species of Mazama (Mantellatto et al., 2010), three (NVHRT01, NVHRT03 and NVHRT16) to the marsh deer (Leite et al., 2007) and one (BM757) to O. bezoarticus (Cossé et al., 2007).

The PCR reactions were standardized to a final volume of $15 \mu \mathrm{L}$, containing $1 \mathrm{X}$ of Taq buffer $(10 \mathrm{mM}$ Tris- $\mathrm{HCl} \mathrm{pH} 8.4,50 \mathrm{mM} \mathrm{KCl}, 2 \mathrm{mM} \mathrm{MgCl} 2), 120 \mu \mathrm{M}$ of dNTPs, $0.4 \mathrm{U}$ of Taq polymerase (Invitrogen), $45 \mathrm{ng}$ of genomic DNA and $0.08 \mathrm{mM}$ of each primer. The same temperature cycles were used for all primers, with variation only in the annealing temperature, as follows: $94{ }^{\circ} \mathrm{C}$ for 5 min, $94^{\circ} \mathrm{C}$ for $1 \mathrm{~min}, 50-59^{\circ} \mathrm{C}$ for $1 \mathrm{~min}$ (depending on the primer pair shown in Table 1 ), $72{ }^{\circ} \mathrm{C}$ for $1 \mathrm{~min}$ and $72{ }^{\circ} \mathrm{C}$ for $10 \mathrm{~min}$. The PCR products were applied to a denaturing polyacrylamide gel and stained with $10 \%$ silver nitrate to evaluate the polymorphism at each locus. After confirming transferability, the loci for individualizing fecal samples collected in the field were selected based on polymorphism (more than three alleles) and the quality and sharpness of the allele bands on the gels. 


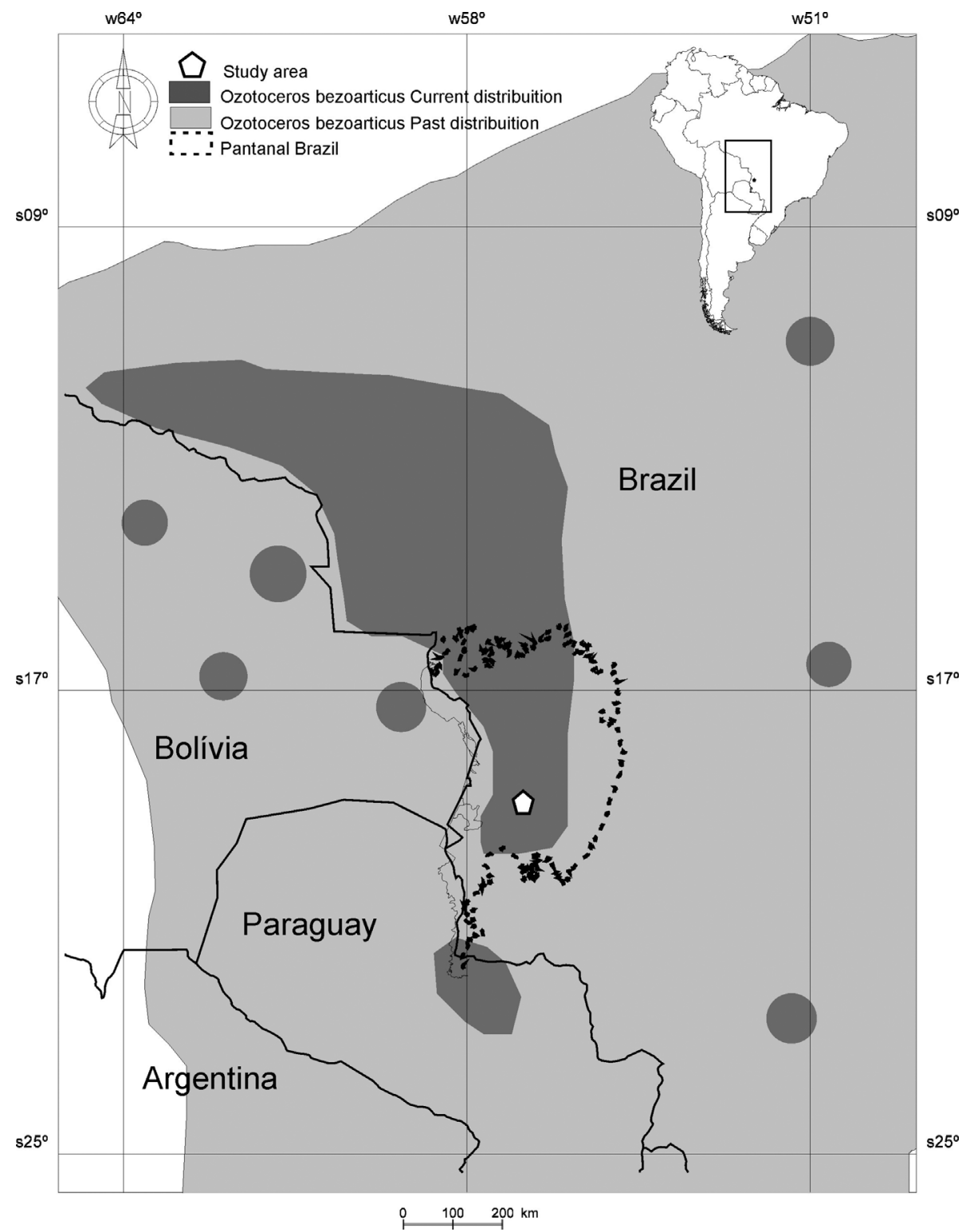

Figure 1 - Map showing the past and current distribution of the pampas deer and the predominant distribution in Brazil. The location of the population studied in this work is highlighted.

\section{Genotyping of fecal samples}

To individualize the 142 fecal samples collected, fluorescent labeling of the PCR products was done by adding fluorescence (HEX, NED or FAM) to one of each primer pair. The reaction had a final volume of $11 \mu \mathrm{L}$, containing $0.5 \mu \mathrm{M}$ of each primer, $1 \mathrm{X}$ buffer, $0.3 \mu \mathrm{L}$ of $\mathrm{MgCl}_{2}, 0.6 \mu \mathrm{L}$ of BSA, $1.0 \mu \mathrm{L}$ of dNTPs, 1.0 unit of Taq polymerase (Platinum ${ }^{\circledR}$ Invitrogen) and $2.6 \mu \mathrm{L}$ of ultrapure water. The remainder of the $11 \mu \mathrm{L}$ reaction volume was completed with DNA sample. The amplicons were then run on ABI 3100 and ABI 3130 automatic sequencers and assigned genotypes using the program GeneMarker v.2.4.2 (SoftGenetics LLC).
To overcome problems such as allelic dropout and false alleles (Taberlet et al., 1996; 1999), the reactions and genotyping were done in duplicate for all samples. When the result obtained was inconsistent with its respective replicate, triplicate and quadruplicate tests of the same samples were run to minimize these genotyping errors. This was done for about $21 \%$ of the total samples, $50 \%$ of these belonging to the locus BM757. The deer were individualized by comparing the genotypes obtained from each fecal sample and considering only those with positive results for at least three microsatellite loci. Since some studies have shown that the success in amplification varies according to locus size (e.g. Oliveira and Duarte, 2013), we also investigated the correlation between these variables by calculating Pearson's correlation coefficient. 
Table 1 - Summary of the 11 microsatellite loci included in the characterization of 13 female pampas deer (Ozotoceros bezoarticus leucogaster) from the Brazilian Pantanal using heterologous primers.

\begin{tabular}{|c|c|c|c|c|c|}
\hline Locus & Fluorescence & Repetition & $\mathrm{T}_{\mathrm{A}}\left({ }^{\circ} \mathrm{C}\right)$ & $\mathrm{N}_{\mathrm{A}}$ & Range (bp) \\
\hline $\mathrm{RT} 1^{1}$ & Fam & $(\mathrm{GT})_{22}$ & 55.5 & 5 & $220-230$ \\
\hline RT06 $^{1}$ & - & $(\mathrm{GT})_{23}$ & 55.5 & 3 & $120-130$ \\
\hline RT0 $7^{1}$ & - & $(\mathrm{GT})_{18}$ & 55.5 & 4 & $190-200$ \\
\hline $\mathrm{RT} 9^{1}$ & Fam & $(\mathrm{GT})_{21}$ & 55.5 & 5 & $120-130$ \\
\hline $\mathrm{RT}_{13}{ }^{1}$ & - & $(\mathrm{GT})_{13}$ & 55.5 & 3 & $290-296$ \\
\hline RT30 $0^{1}$ & Hex & $(\mathrm{GT})_{21}$ & 55.5 & 5 & $200-220$ \\
\hline NVHRT0 $^{2}$ & Ned & $(\mathrm{GT})_{7} \mathrm{GC}(\mathrm{GT})_{12}$ & 50.0 & 5 & $164-200$ \\
\hline NVHRT03 $^{2}$ & Ned & $(\mathrm{CT})_{7} \mathrm{TA}(\mathrm{CA})_{12}$ & 50.0 & 5 & $112-126$ \\
\hline NVHRT16 $6^{2}$ & Hex & $(\mathrm{CA})_{5} \mathrm{TA}(\mathrm{CA})_{5}(\mathrm{TG})_{2} \mathrm{CG}(\mathrm{CA})_{19}$ & 50.0 & 7 & $152-192$ \\
\hline $\mathrm{CA} 71^{3}$ & Hex & $(\mathrm{CT})_{12}$ & 50.0 & 3 & $300-310$ \\
\hline $\mathrm{BM} 757^{4}$ & Fam & $(\mathrm{GT})_{17}$ & 58.5 & 7 & $195-227$ \\
\hline
\end{tabular}

$\mathrm{N}_{\mathrm{A}}$ - number of alleles, $\mathrm{T}_{\mathrm{A}}$ - annealing temperature in degrees Celsius, - no fluorescence, i.e., locus was not used in genotyping. References: ${ }^{1}$ Wilson et al. (1997), ${ }^{2}$ Roed and Midthjell (1998), ${ }^{3}$ Gaur et al. (2003), ${ }^{4}$ Bishop et al. (1994).

\section{Genetic characterization of the population}

For the next analysis, we considered only the genotypes of adult deer individualized in the previous step, thereby avoiding overlapping generations. The HardyWeinberg equilibrium (HWE), expected $\left(H_{E}\right)$ and observed heterozygosity $\left(H_{O}\right)$, and analyses of linkage disequilibrium were calculated using the program Genepop 1.2 (Raymond and Rousset, 1995), with the following parameters for the Markov chain Monte Carlo (MCMC): dememorization 10,000 , batches 1,000 , and iterations per batch 10,000. The Bonferroni correction (Rice, 1989) was applied to the nominal value of $\alpha=0.05$ to adjust the levels of significance in the analysis. The presence of errors in the genotyping was assessed using the Micro-Cheker program (Van Oosterhout et al., 2004). The probability of genetic identity $\left(P_{I D}\right)$, which corresponds to the probability of two random individuals exhibiting the same genotype (Chakravarati and $\mathrm{Li}, 1983$ ), and the probability of paternity exclusion $(Q)$, which corresponds to the force with which a locus excludes an individual from being the mother of an offspring (Weir 1996), were estimated using the program Identity 1.0 (Wagner and Sefc, 1999).

\section{Results}

\section{Cross-amplification}

All pampas deer loci tested showed successful crossamplification and were polymorphic since more than two alleles per locus were evident in blood samples from the 13 females studied (Table 1). Six loci (CA71, BM757, NVHRT16, NVHRT03, RT01 and RT09) attained our quality criteria (see Heterologous primers section) and were used for fecal sample individualization.

\section{Individualization of fecal samples}

At least one microsatellite locus was amplified from the 142 fecal samples analyzed, but the six selected loci were amplified in only $40.8 \%$ of the samples. Considering our selection criteria (sample genotyping for more than three loci), only 131 samples were used in the sample individualization step. The latter analysis allowed us to identify 74 deer (50 adults, 19 young and 5 undetermined) during the study period.

The six loci used showed an amplified microsatellite fragment size of 112-310 bp (Table 1). There was no correlation between successful amplification and microsatellite locus size $\left(\mathrm{R}^{2}=0.0082\right.$ and $\left.p=0.86\right)$. The smallest amplified fragment (locus NVHRT03, ranging from 112-126 bp) showed $76.8 \%$ successful amplification in the 142 samples tested, while the largest fragment (locus CA71, ranging from $300-310 \mathrm{bp}$ ) was successfully amplified in $69 \%$ of samples. The locus with the greatest success in amplification (93.7\%) was RT01 (220-230 bp).

\section{Genetic characterization of the population}

Based on the analysis of 50 samples from adult deer (27 males and 23 females, see Table S1) in which there were no overlapping generations, only locus CA71 showed Hardy-Weinberg disequilibrium (Table 2), probably because of the presence of null alleles. For the remaining loci, no null, stutter or dropout alleles were detected. All the loci showed linkage disequilibrium. The mean number of alleles was 11.5 and the mean expected heterozygosity $\left(\mathrm{H}_{\mathrm{E}}\right)$ was 0.75 (Table 2). The mean probability of identity ( $\left.\mathrm{P}_{\mathrm{ID}}\right)$ obtained for the six loci was $1.74 \times 10^{-8}$, while the mean probability of paternity exclusion $(Q)$ was $>99 \%$. 
Table 2 - Characterization of six microsatellite loci transferred to Ozotoceros bezoarticus leucogaster based on the genotyping of 50 individuals in a population from the Brazilian Pantanal.

\begin{tabular}{lcccccc}
\hline Locus & $\mathrm{N}_{\mathrm{A}}$ & HWE & $H_{E}$ & $H_{O}$ & $Q$ & $P_{I D}$ \\
\hline RT01 & 13 & 0.65 & 0.86 & 0.84 & 0.74 & 0.03 \\
RT09 & 6 & 0.57 & 0.70 & 0.69 & 0.45 & 0.14 \\
BM757 & 17 & 0.49 & 0.90 & 0.92 & 0.80 & 0.02 \\
NVHRT03 & 11 & 0.03 & 0.86 & 0.76 & 0.73 & 0.03 \\
NVHRT16 & 17 & 0.62 & 0.90 & 0.90 & 0.80 & 0.02 \\
CA71 & 5 & 0.00 & 0.29 & 0.24 & 0.16 & 0.51 \\
Mean & 11.5 & 0.39 & 0.75 & 0.72 & 0.99 & $1.74 \times 10^{-8}$ \\
\hline
\end{tabular}

HWE - Probability values obtained by the H-W equilibrium test, $H_{E}-$ expected heterozygosity, $H_{O}$ - observed heterozygosity, $\mathrm{N}_{\mathrm{A}}$ - number of alleles, $Q$ - probability of paternity exclusion and $P_{I D}$ - probability of genetic identity.

\section{Discussion}

By combining a non-invasive method (fecal DNA analysis) with the use of microsatellite markers we conducted the first population genetic study on a large sample of pampas deer in the Brazilian Pantanal, in Mato Grosso do Sul, home to the largest population of this species.

The six loci studied were amplified in at least $69 \%$ of the samples, more than required for deer individualization analysis, for which at least three loci per sample were amplified, as recommended by Miotto et al. (2011). The total probability of genetic identity $\left(P_{I D}\right)$ was close to $99 \%$, indicating that the six loci were more than adequate to individualize the fecal samples and that the individualization of 74 deer based on these loci was reliable. Furthermore, the low value for the probability of paternity exclusion for all the loci showed that they formed a set of appropriate codominant markers for paternity/maternity and genetic studies in pampas deer populations.

The amplification of at least one microsatellite locus in all the samples and 5-6 loci in $\sim 70 \%$ of the samples analyzed indicated a high rate of success for fecal DNA. These results indicate that the use of fresh fecal samples can enhance the success of studies using fecal DNA samples (Oliveira and Duarte, 2013). In contrast, based on samples collected in northern Chile during the summer, Espinosa et al. (2015) concluded that fresh feces (based on the presence of mucus or deer observed defecating) and non-fresh feces (no mucus, deer not observed defecating) were equally efficient for successful DNA amplification in ungulate species.

The data obtained here revealed high genetic diversity in the pampas deer population of the Brazilian Pantanal (Table 2). As expected, the mean number of alleles per locus was higher with the increase in sample size. The mean number of alleles per locus for the Pantanal population $(\mathrm{n}=$ 50) was 11.5 , but was 5.8 based on the genotypes of five individuals from the same population (Cossé 2010, PhD thesis, Universidade de la Republica, Uruguay) (for geno- types, see page 190). On the other hand, the expected mean heterozygosity $\left(\mathrm{H}_{\mathrm{E}}=0.75\right)$ for the Pantanal population $(\mathrm{n}=$ 50) was slightly lower than that reported (Cossé M, 2010, $\mathrm{PhD}$ thesis, Universidade de la Republica, Uruguay) $\left(\mathrm{H}_{\mathrm{E}}=\right.$ $0.87, \mathrm{n}=5$ ), suggesting that the genetic variability of the Pantanal population is slightly lower than previously described for the same type of genetic marker. The high genetic diversity observed in this population of pampas deer was also observed in a study of dominant nuclear markers of random amplified polymorphic DNA (RAPD) (Rodrigues et al., 2007). Studies using mitochondrial markers from the D-loop control region (González et al., 1998; Braga et al., 2005) and from cytochrome b (Braga et al., 2005) also confirmed the high nucleotide diversity of the species. Consequently, González et al. (1998) suggested that the control region in pampas deer is one of the most polymorphic among mammals and that the large number of haplotypes indicates this was once a much more abundant species of deer.

The high genetic diversity reported here strongly supports the relevance of this $O$. bezoarticus population. The high quality habitats of this population are changing in response to political and economic policies that encourage the installation of major development projects, the conversion of natural landscapes to allow the introduction of exotic grasses and a variety of other practices. One example of the latter is the deforestation of areas of mountain ranges, with a phytophysiognomy characterized by sandy ridges under Cerrado vegetation, that are one or two meters above the level of the fields, so they generally do not flood (Junk and Silva, 1999). Another is the systematic burning of the Caronal, a phytophysiognomy characterized by savanna vegetation predominantly covered by wild lemongrass (Elyonurus muticus), to establish and improve grazing pastures (Cardoso et al., 2000a,b; 2003). These examples raise concern regarding the conservation of the wild populations that inhabit these biomes (Cunha and Junk, 2009).

Based on the set of nuclear microsatellite markers evaluated here, further research should be done to compare the genetic diversity of different populations of pampas deer and to determine whether recent structuring has occurred in different locations. New studies should also analyze whether the structuring observed using mitochondrial markers for populations in Brazil (González et al., 1998; Braga et al., 2005), Argentina and Uruguay (González et al., 1998) can be corroborated, since the exclusive use of mitochondrial markers may yield an artificial subdivision, an effect of female philopatry. Finally, it seems reasonable to affirm that the combination of techniques described here could easily be replicated in other species of Cervidae, with the appropriate methodological adjustments.

\section{Acknowledgments}

The authors thank all those involved in the fieldwork who were responsible for collecting fecal samples and ob- 
taining blood samples from the deer. We also thank John Boer (laboratory technician), Embrapa Pantanal and Fazenda Nhumirim for logistical support, Hector Herrera Junior, the owner of Fazenda Alegria, where fecal collections were done, Luiz Alberto Pellegrin for help with mapping and two anonymous reviewers for their useful comments. This work was supported by the São Paulo Research Foundation (FAPESP, grant no. 2009/04253-5).

\section{References}

Araújo Júnior JP, Nogueira MF, Cruz TF and Haigh JC (2010) Viral diseases. In: Duarte JMB and González S (eds) Neotropical Cervidology: Biology and Medicine of Latin American Deer. Funep/IUCN, Jaboticabal, pp 330-341.

Bishop MD, Kappes SM, Keele JW, Stone RT, Sunden SLF, Hawkins GA, Toldo SS, Fries R, Grosz MD, Yoo J, et al. (1994) A genetic linkage map of cattle. Genetics 136:619639.

Braga FG, González S and Maldonado JE (2005) Characterization of the genetic variability of pampas deer in the state of Paraná. Deer Specialist Group News 20:2-4.

Cabrera A (1943) Sobre la sistematica del venado y su variacion individual y geografica. Revta Mus La Plata 3:5-41.

Cardoso EL, Crispim SMA, Rodrigues CAG and Barioni Júnior W (2000a) Biomassa aérea e produção primária do estrato herbáceo em campo de Elyonurus muticus submetido à queima anual, no Pantanal. Pesq Agropec Bras 35:1501-1507.

Cardoso EL, Crispim SMA, Rodrigues CAG and Barioni Júnior W (2000b) Composição e dinâmica da biomassa aérea após a queima em savana gramíneo lenhosa no Pantanal. Pesq Agropec Bras 35:2309-2316.

Cardoso EL, Crispim SMA, Rodrigues CAG and Barioni Júnior W (2003) Efeitos da queima na dinâmica da biomassa aérea de um campo nativo no Pantanal. Pesq Agropec Bras 38:747-752.

Catão-Dias JL and Camargo CMS (2010) Capture myopathy. In: Duarte JMB and González S (eds) Neotropical Cervidology: Biology and Medicine of Latin American Deer. Funep/IUCN, Jaboticabal, pp 324-329.

Chakravarati A and Li CC (1983) The effect of linkage on paternity calculations. In: Walkera RH (ed) Inclusion Probabilities in Parentage Testing. American Association of Blood Banks, Arlington, pp 411-422.

Cossé M, González S and Maldonado JE (2007) Cross-amplification tests of ungulate primers in the endangered Neotropical pampas deer (Ozotoceros bezoarticus). Genet Mol Res 4:1118-1122.

Cunha NC and Junk WJ (2009) A preliminary classification of habitats of the Pantanal of Mato Grosso and Mato Grosso do Sul, and its relation to national and international wetland classification systems. In: Junk WJ, Da Silva CJ, Nunes da Cunha C and Wantzen KM (eds) The Pantanal: Ecology, Biodiversity and Sustainable Management of a Large Neotropical Seasonal Wetland. Pensoft, Sofia, pp 127-141.

Duarte JMB (2006) Artiodactyla - Cervidae (Veado-catingueiro, Veado-campeiro, Cervo-do-pantanal). In: Cubas ZS, Silva JCR and Catão-Dias JL (eds) Tratado de Animais Selvagens. Roca Ltda, São Paulo, pp 641-664.
Duarte JMB (2008) A technique for the capture of the freeranging marsh deer (Blastocerus dichotomus). J Zoo Wildl Med 39:596-599.

Duarte JMB, Merino ML, González S, Nunes ALV, Garcia JM, Szabó MPJ, Pandolfi JR, Arantes IG, Nascimento AA, Machado RZ, et al. (2001) Order Artiodactyla family Cervidae (deer) In: Fowler ME and Cubas ZS (eds) Biology, Medicine, and Surgery of South American Wild Animals. Iowa State University Press, Ames, pp 402-422.

Duarte JMB, Uhart MM and Galvez CES (2010) Capture and physical restraint. In: Duarte JMB and González S (eds) Neotropical Cervidology: Biology and Medicine of Latin American Deer. Funep/IUCN, Jaboticabal, pp 218-227.

Duarte JMB, Vogliotti A, Zanetti ES, Oliveira ML, Tiepolo LM, Rodrigues FL, Almeida LB and Braga, FG (2012) Biodiversidade Brasileira - Avaliação do Estado de Conservação dos Ungulados. Instituto Chico Mendes de Conservação da Diversidade, Brasília, ano II, n 3, pp 20-32.

Espinosa MI, Bertin A, Squeo SA, Cortés A and Gouin N (2015) Comparison of DNA extraction methods for polymerase chain reaction amplification of guanaco (Lama guanicoe) fecal DNA samples. Genet Mol Res 14:400-406.

Frankhan R, Ballou JD and Briscoe DA (2004) A Primer of Conservation Genetics. Cambridge University Press, Cambridge, $236 \mathrm{pp}$.

Gaur A, Singh A, Arunabala V, Uumapathy G, Shailaja K and Singh L (2003) Development and characterization of 10 novel microsatellite markers from Chital deer (Cervus axis) and their cross-amplification in other related species. Mol Ecol Notes 3:607-609.

González S (1998) Estado de conservação dos cervídeos da América do Sul. Logos Tempo e Ciência 2:61-65.

González S, Maldonado JE, Leonard JA, Vilà C, Duarte JMB, Merino M, Brum-Zorrilla N and Waine RK (1998) Conservation genetics of the endangered pampas deer (Ozotoceros bezoarticus). Mol Ecol 7:47-56.

González S, Álvarez-Valin F and Maldonado JE (2002) Morphometric differentiation of endangered pampas deer (Ozotoceros bezoarticus), with description of new subspecies from Uruguay. J Mammal 8:1127-1140.

González S, Cossé M, Góss Braga F, Vila AR, Merino ML, Dellafiore C, Cartes JL, Maffei L and Dixon MG (2010) Pampas deer Ozotoceros bezoarticus (Linnaeus 1758). In: Duarte JMB and González S (eds) Neotropical Cervidology: Biology and Medicine of Latin American Deer. Funep/IUCN, Jaboticabal, pp 119-132.

Greenwood JJD (1996) Basic techniques. In: Sutherland WJ (ed) Ecological Census Techniques, A Handbook. Cambridge University Press, Cambridge, pp 11-110.

Junk WJ and Silva CJ (1999) O conceito do pulso de inundação e suas implicações para o Pantanal de Mato Grosso. Anais do II Simpósio sobre Recursos Naturais e Sócio-econômicos do Pantanal, Manejo e Conservação. EMBRAPA-CPAP, Brasilia, pp 17-28.

Leite KCE, Collevatti RG, Menegasso TR, Tomas WM and Duarte JMB (2007) Transferability of microsatellite loci from Cervidae species to the endangered Brazilian marsh deer, Blastocerus dichotomus. Genet Mol Res 6:325-330.

Lounsberry ZT, Forrester TD, Olegario MT, Brazeal JL, Wittmer HU and Sacks BN (2015) Estimating sex-specific abundance in fawning areas of a high-density Columbian black- 
tailed deer population using fecal DNA. J Wildl Manag 79:39-49.

Mantellatto AMB, Carnelossi EAG and Duarte JMB (2010) Transferability of microsatellite loci from exotic Cervidae to Brazilian brocket deer (Mazama spp, Mammalia: Cervidae). Genet Mol Res 9:277-282.

Miotto RA, Cervini M, Figueiredo MG, Begotti RA and Galetti Jr PM (2011) Genetic diversity and population structure of pumas (Puma concolor) in southeastern Brazil: Implications for conservation in a human-dominated landscape. Conserv Genet 12:1447-1455.

Mourão GM, Coutinho M, Mauro R, Campos Z, Tomas WM and Magnusson W (2000) Aerial surveys of caiman, marsh deer and pampas deer in the Pantanal Wetland of Brazil. Biol Conserv 92:175-183.

Oliveira ML and Duarte JMB (2013) Amplifiability of mitochondrial, microsatellite and amelogenin DNA loci from fecal samples of red brocket deer Mazama americana (Cetartiodactyla, Cervidae). Genet Mol Res 12:44-52.

Raymond M and Rousset F (1995) GENEPOP (version 1.2): Population genetics software for exact tests and ecumenicism. J Hered 86:248-249.

Rice WR (1989) Analyzing tables of statistical tests. Evolution 43:223-225.

Røed KH and Midthjell L (1998) Microsatellite in reindeer, Rangifer tarandus, and their use in other cervids. Mol Ecol 7:1773-1776.

Rodrigues FP, Garcia JF, Ramos PRR, Bortolozzi J and Duarte JMB (2007) Genetic diversity of two Brazilian populations of the pampas deer (Ozotoceros bezoarticus, Linnaeus 1758). Braz J Biol 67:805-811.

Taberlet P, Griffin S, Goossens B, Questiau S, Manceau V, Escaravage N, Waits LP and Bouvet J (1996) Reliable genotyping of samples with very low DNA quantities using PCR. Nucleic Acids Res 24:3189-3194.

Taberlet P, Waits LP and Luikart G (1999) Noninvasive genetic sampling: Look before you leap. Trends Ecol Evol 14:323327.
Tomas WM, McShea W, Miranda GHB, Moreira JR, Mourão G and Lima Borges PA (2001) A survey of a pampas deer, Ozotoceros bezoarticus leucogaster (Artiodactyla: Cervidae), population in the Pantanal wetland, Brazil, using the distance sampling technique. Anim Biodivers Conserv 24:101-106.

Van Oosterhout C, Hutchinson WF, Wills DPM and Shipley P (2004) Micro-Checker: Software for identifying and correcting genotyping errors in microsatellite data. Mol Ecol Notes 4:535-538.

Wagner HW and Sefc KM (1999) Identity 1.0. Centre for Applied Genetics, University of Agricultural Sciences, Vienna.

Wilson GA, Strobeck C, Wu L and Coffin JW (1997) Characterization of microsatellite loci in caribou, Rangifer tarandus, and their use in other artiodactyls. Mol Ecol 6:697-699.

Yamashiro A, Endo A, Kuwataka H, Matsumoto $\mathrm{Y}$ and Yamashiro T (2015) Geographic origin and genetic structure of introduced Sika deer, Kerama deer (Cervus nippon keramae) on Ryukyus inferred from mitochondrial DNA sequences. Mammal Study 40:187-192.

\section{Internet Resources}

González S, Jackson III JJ and Merino ML (2016) Ozotoceros bezoarticus. The IUCN Red List of Threatened Species. http://www.iucnredlist.org/details/15803/0 (accessed 27 October, 2016).

\section{Supplementary material}

The following online material is available for this article: Table S1 - List of the 50 samples used in the genetic characterization of pampas deer.

Associate Editor: Fabrício Rodrigues dos Santos.

License information: This is an open-access article distributed under the terms of the Creative Commons Attribution License (type CC-BY), which permits unrestricted use, distribution and reproduction in any medium, provided the original article is properly cited. 